\title{
Cytotoxicity of Aspergillus Fungi as a Potential Infectious Threat
}

\author{
Agnieszka Gniadek \\ Department of Medical and Environmental Nursing, Faculty of Health Sciences, \\ Jagiellonian University Medical College, Kraków, \\ Poland
}

\section{Introduction}

Moulds constitute the largest group of bacteria, prevailing both in the indoor and outdoor air. Approximately 200000 species of moulds have been identified so far, where only a small group of around 200 may present a threat to human health. Fungi from Aspergillus species are among the moulds considered to be most pathogenic. They also constitute the group of most pathogenic moulds most frequently isolated from the environment. Over 250 types of this species are known; about 50 of them were precisely described before the year 2000 (Klich, 2009). Pathogenicity, due to their toxicity, was also documented in other species: Aspergillus fumigatus, Aspergillus flavus, Aspergillus ochraceus, Aspergillus niger, Aspergillus versicolor, Aspergillus parasiticus. Aspergillus nidulans, Aspergillus ustus, Aspergillus glaucus, Aspergillus clavatus, Aspergillus sydowii and Aspergillus terreus. Their taxonomic identification is still an open topic because of their morphological variability and ability to produce metabolites; new species which exhibit adverse health effects to humans are constantly being detected. Aspergillus lentulus is one of the recently detected species of considerable clinical importance; it reveals similarity to Aspergillus fumigatus, one of the most pathogenic fungus for humans (Balajee et al., 2005).Table 1 presents the classification of species of fungi pathogenic to humans from the Aspergillus species. The list has been created by the authors of "Atlas Grzybów Chorobotwórczych Człowieka" ("Atlas of Fungi Pathogenic to Humans") (Krzyściak et al., 2011).

\section{Fungal metabolites of Aspergillus species present a threat for human health}

In their metabolic process, moulds produce mycotoxins. Those natural products, poisonous to humans and animals, are created as the result of a secondary metabolic process of fungi, when grown on organic substrates. Chemical structure of these metabolites varies, however, they are largely of small molecular mass, which conditions their varied toxic characteristics. So far over 400 metabolites produced by moulds have been identified from different genus of fungi: Aspergillus sp., Penicillium sp., Fusarium sp., Alternaria sp. Trichothecium sp. or Stachybotrys sp. Secondary metabolites of fungi from Aspergillus species are: ochratoxin A, aflatoxin B1, aflatoxins G1 and M1, trichothecenes, sterigmatosystin, patulins, gliotoxins or cyclopiazonic acid. Table 2 presents metabolites produced by the selected, most pathogenic 


\begin{tabular}{|c|c|c|c|}
\hline Subtype & Section & Teleomorph & Species linked to infections in humans \\
\hline \multirow[t]{2}{*}{ Aspergillus } & Aspergillus & Eurotium & $\begin{array}{ll}\text { A. } & \text { chevalieri (Eurotium chavalieri) } \\
\text { A. } & \text { glaucus (Eurotium herbariorum) } \\
\text { A. } & \text { hollandicus (Eurotium amstelodami) } \\
\text { A. } & \text { reptans (Eurotium repens) } \\
\text { A. } & \text { rubrobrunneus (Erotium rubrum) } \\
\text { A. } & \text { sejunctus } \\
\end{array}$ \\
\hline & Restricti & & $\begin{array}{ll}\text { A. } & \text { caesiellus } \\
\text { A. } & \text { conicus } \\
\text { A. } & \text { pencilliodes } \\
\text { A. } & \text { restrictus } \\
\end{array}$ \\
\hline \multirow[t]{2}{*}{ Fumigati } & Fumigati & Neosartorya & $\begin{array}{l}\text { A. fischerianus (Neosartorya fischeri) } \\
\text { A. fumigatus } \\
\text { A. fumisynnematus } \\
\text { A. lentulus } \\
\text { A. spinosus (Neosartorya spinosa) } \\
\text { A. thermomutans (Neosartorya } \\
\text { A. pseudofischeri) } \\
\text { viridinutans } \\
\text { Neosartorya coreana - no confirmation of } \\
\text { pathogenicity in humans } \\
\text { Neosartorya fennelliae - no confirmation } \\
\text { of pathogenicity in humans } \\
\text { Neosartorya hiratsukae } \\
\text { Neosartorya udagawae }\end{array}$ \\
\hline & Cervini & & \\
\hline Ornati & Ornati & Neocarpentels & \\
\hline Clavati & Clavati & n.n. & $\begin{array}{l}\text { A. clavatoanicus } \\
\text { A. clavtus }\end{array}$ \\
\hline \multirow[t]{5}{*}{ Nidulantes } & Usti & & $\begin{array}{l}\text { A. calidoustus } \\
\text { A. deflectus } \\
\qquad \text { A. ustus }\end{array}$ \\
\hline & Versicolores & & $\begin{array}{ll}\text { A. } & \text { granulosus } \\
\text { A. } & \text { janus } \\
\text { A. } & \text { sydowii } \\
\text { A. } & \text { versicolor } \\
\end{array}$ \\
\hline & Terrei & Fennellia & $\begin{array}{l}\text { A. alabamensis } \\
\text { A. terreus } \\
\end{array}$ \\
\hline & Flavipedes & Fennellia & $\begin{array}{ll}\text { A. } & \text { carneus } \\
\text { A. } & \text { flavipes } \\
\text { A. } & \text { niveus (Fennellia nivea) } \\
\end{array}$ \\
\hline & Nidulantes & Emericella & $\begin{array}{ll}\text { A. } & \text { nidulans (Emericella nidulans) } \\
\text { A. } & \text { quadrilineata A. tetrazonus } \\
& \text { (Emericella quadrilineata) } \\
\text { A. } & \text { unguius (Emericella unguis) } \\
\end{array}$ \\
\hline \multirow[t]{2}{*}{ Circumdati } & Circumdati & Neopetrmyces & $\begin{array}{ll}\text { A. } & \begin{array}{l}\text { alutaceus (isolated from sputum, } \\
\text { pathogenicity not confirmed in }\end{array} \\
\text { humans) } \\
\text { A. ochraceus } \\
\text { A. } & \text { sclerotiorum }\end{array}$ \\
\hline & Flavi & Petromyces & $\begin{array}{l}\text { A. alliaceus } \\
\text { A. avenaceus } \\
\text { A. beijingensis }\end{array}$ \\
\hline
\end{tabular}




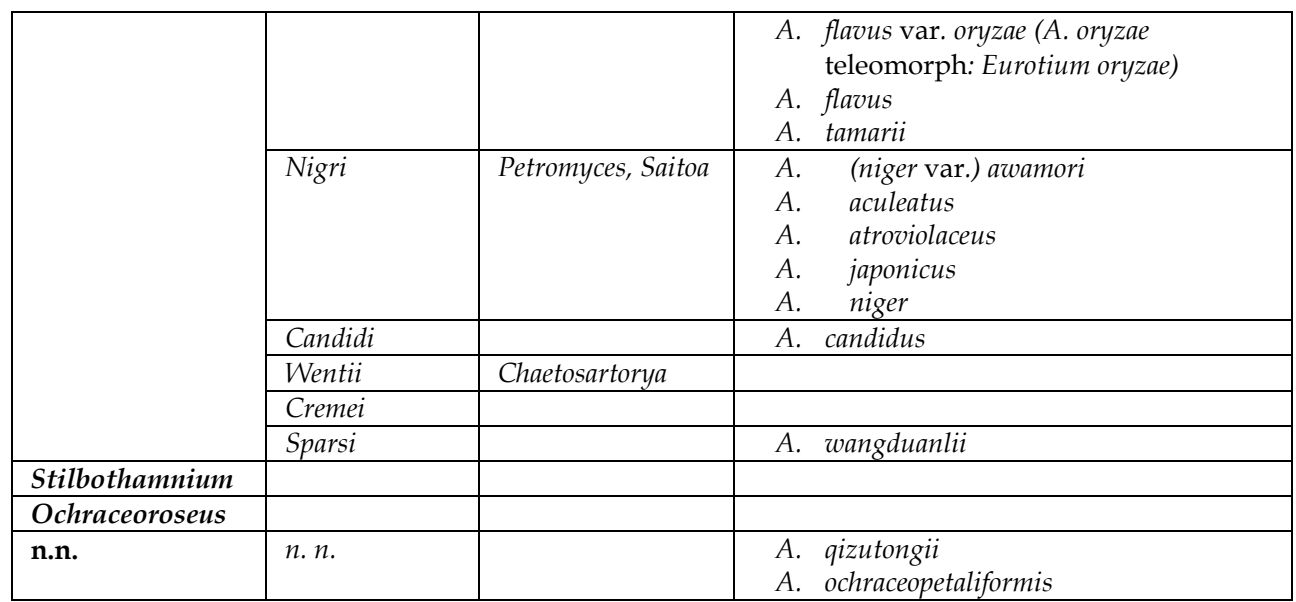

Table 1. Classification of pathogenic to humans Aspergillus species.

to humans Aspergillus species . (Krzyściak et al., 2011; Bräse et al., 2009; Skaug et al., 2001; Pitt et al., 2000; Smith et al., 1995)

\begin{tabular}{|c|l|l|}
\hline No & Species & Metabolites \\
\hline $\mathbf{1}$ & Aspergillus fumigatus & $\begin{array}{l}\text { gliotoxin, verruculogen, fumitremorgin A and B, } \\
\text { fumitoxin, tryptoguivaline, fumigallin, helvolic acid } \\
\text {, sphingofungins, brevianamide A, coumarin }\end{array}$ \\
\hline $\mathbf{2}$ & Aspergillus flavus & $\begin{array}{l}\text { kojic acid, 3-nitropropionic acid, cyclopiazonic acid, } \\
\text { aflatoxin B1, B2, G1, G2, aspergillic acid, } \\
\text { violaxanthin, aspertoxin }\end{array}$ \\
\hline $\mathbf{3}$ & Aspergillus niger & $\begin{array}{l}\text { naphto-g-pyrones, malformin, ochratoxin A, toxic } \\
\text { oxalates, violaxanthin }\end{array}$ \\
\hline $\mathbf{4}$ & Aspergillus ochraceus & $\begin{array}{l}\text { penicillic acid, ochratoxin A and B, xanthomeganin, } \\
\text { viomellein, violaxanthin, circumdatin A, B, C }\end{array}$ \\
\hline $\mathbf{5}$ & Aspergillus versicolor & $\begin{array}{l}\text { sterigmatocystin, nidulotoxin, antrachinons, } \\
\text { anthraquinoid }\end{array}$ \\
\hline $\mathbf{6}$ & Aspergillus candidus & $\begin{array}{l}\text { kojic acid, terphenyllin, candidulin, xanthoascin, } \\
\text { beta nitropropionic acid }\end{array}$ \\
\hline $\mathbf{7}$ & Aspergillus terreus & $\begin{array}{l}\text { terreic acid, patulin, citrinin, citreoviridin, } \\
\text { lovastatin, gliotoxin, terrain, patulin }\end{array}$ \\
\hline $\mathbf{8}$ & Aspergillus nidulans & sterigmatocystin, penicillin, cotanin, nidulotoxin \\
\hline $\mathbf{9}$ & Aspergillus clavatus & $\begin{array}{l}\text { patulin, cytochalasin E, tryptoguivaline, kojic acid, } \\
\text { clavatol, kotanin }\end{array}$ \\
\hline $\mathbf{1 0}$ & Aspergillus lentulus & $\begin{array}{l}\text { gliotoxin, cyclopiazonic terreic acid, neosartorin, } \\
\text { auranthine and pyripyropenes A, E }\end{array}$ \\
\hline $\mathbf{1 1}$ & Aspergillus parasiticus & Aflatoxins A1, B1, G1, G2 \\
\hline
\end{tabular}

Table 2. Metabolites of selected species of Aspergillus fungi. 
Natural metabolites produced by fungi are for the most part cytotoxic to different cellular structures and depress their key processes such as RNA and DNA synthesis (Burr, 2001). Mycotoxins differ with respect to their nature, action towards target cells, cellular structures and their internal processes. Best described mycotoxins produced by fungi of the Aspergillus species are aflatoxins and ochratoxins. Aflatoxins are highly saturated heterocyclic compounds which contain elements of furan. Ochratoxins constitute a group of poliketides derived from isocoumarin, related to L-phenylalanine. Degradation of ochratoxin A within the human body produces (4-R)-4 hydroxyochratoxin A and ochratoxin $\alpha$, which create an albumin bond in the plasma. Creation of such bond facilitates the substances` persistence in the human body for an extended period of time (Budak, 1998).

Influence on the health in exposed individuals exerted by secondary metabolites includes carcinogenic, teratogenic, mutagenic, hepatotoxic and nephrotoxic action (it particularly concerns aflatoxin $A_{1}$ and ochratoxin A) (Fischer \& Dott 2003;Burr, 2001). Sterigmatocystin is one of the aflatoxin precursors on its biosynthesis pathway and its carcinogenic action is only slighly lower than that of aflatoxin itself. Gliotoxin is considered to be responsive to immunosuppression and cellular apoptosis; it is also a likely virulence factor in mycoses caused by A. fumigatus. Gliotoxin is a very frequently detected toxin in the serum of patients suffering from aspergillosis. (Bok et al., 2005). This toxin is present in the serum of animals with a natural $A$. fumigatus infection and in cancer patients with invasive aspergillosis (Lewis et al., 2005).

This was confirmed in the findings obtained by Kupfahl, in which analysis of gliotoxin was performed in 158 Aspergillus strains (100 A. fumigatus) originating from patients with invasive aspergillosis and from the environment. During analysis of the strains and their ability to produce gliotoxin he discovered that gliotoxin was detected in the majority of $A$. fumigatus strains isolated both from clinical materials and from the environment $(98 \%$ and 96\% respectively) (Kupfahl et al., 2008).

The variety of metabolites produced by fungi of the Aspergillus species ( A. fumigatus produces as well fumigallin, helvolic acid, tryptoguivaline, $A$. candidus kojic acid, terphenyllin, A. ochraceus penicillic acid or viomellein, while A. niger produces malformin) equips the fungi with multiple options of invading the host's body, at the same time limiting the therapeutic options resulting from targeted prophylaxis. As it turns out, applying targeted chemoprophylaxis does not always prove to be effective, as the medicine does not affect all of the metabolites produced just by one strain of fungi (Bräse et al., 2009; Domsch et al, 2007; Ribeiro et al., 2005; Raper \& Fennell, 1965).

\section{Epidemiology of infection and clinical health outcome, as caused by fungi of the Aspergillus species}

Fungi of the Aspergillus species are typical isogenic opportunistic bacteria, which for the most part fail to trigger an infection with a healthy person; however, they constitute a threat predominantly to persons with immunity disorders. Factors which facilitate the conditions necessary for a fungal invasion are: disturbances in the functions of $\mathrm{T}$ lymphocytes, phagocytes as well as the reticuloendothelial system, chemo- and radiotherapy, skin incisions related surgery, therapy or care. Risk factors for developing an invasive aspergillosis are chronic neutropenia (exceeding 3 weeks), corticosteroid treatment, 
hematological neoplasms, cytotoxic treatment, AIDS- Acquired Immune Deficiency Syndrome and bone marrow transplant. Certain influence has also been attributed to cytomegalovirus (CMV) contraction. Treatment with infliximab, a monoclonal antibody against tumour necrosis (TNFa), has been described in literature as being a determining factor for aspergillosis. Mechanisms, through which the predisposition factors intensify invasiveness of fungi of the Aspergillus species, act through or directly at the host, or the fungus, or both. Factors which determine pathogenicity of the Aspergillus fungi are multiple polar or neutral lipids, phenolic compounds and heterocyclic toxins (mycotoxins). An additional factor intensifying the pathogenicity of the Aspergillus fungi is their capacity to produce various proteolytic enzymes e.g. protease, which assist fungal colonisation in the infected host tissues (Türel, 2011; Kurnatowski \&Miśkiewicz, 2009; Macura, 1998).

A source of infection with Aspergillus fungi may be another infected person, in whose body the fungal process develops, but primarily it is the hospital environment: air, water pipe system, ventilation system, hospital food as well as the medical equipment. For isogenic fungi of the Aspergillus type the obvious portal of entry is the respiratory system of a sick person, as well as skin with lesions, e.g. a burn or damaged cornea. Infection within the respiratory system develops as a result of inhalation of the fungal spores present in the air. Very often, prior to development of aspergillosis, a patient`s oronasal cavity is subject to fungal spore colonization. A developing fungus located in the lungs (incubation period spans between 2 days to 3 months) results in haemorrhagic infarctions, which cause a further transmission of the infection through the bloodstream to the brain, liver, spleen, kidneys, pericardium or skin (Mortensen, 2011; Garczewska, 2008)

For patients with lymphopenia - where the number of CD4 cells is lower than $0.2 \times 10 \mathrm{e} / 1$ most of the cases where the respiratory tract is colonized with Aspergillus, aspergillosis may develop as a result. With immunosuppressed patients, e.g. those suffering from hematological neoplasms, the most predominant form of fungal infection is invasive aspergillosis in $70 \%$ of cases caused by A. fumigatus. A variant of aspergillosis a little less common is general aspergillosis which affects central nervous system, sinuses, kidneys, skin or bones. Observational studies (a five year period of observation carried out on 3228 patients who underwent HSCT (haematopoietic stem cell transplant) at 11 transplant wards in Italy, where fungal infection prophylaxis was implemented by means of use of fluconazole, fungal infections were observed in 121 patients $(3.7 \%)$, where $75 \%$ of cases were invasive aspergillosis, mostly of Aspergillus aetiology (Asano-Mori, 2010; Pagano, 2007). Unfortunately, Aspergillus fungal infections display a high mortality rate. In untreated aspergillosis, mortality rate can soar as high as $100 \%$, and in the cases where treatment is introduced it drops only slightly down to $60 \%$. One of the patient groups highly susceptible to invasive fungal infections caused by Aspergillus is the hematooncologic patients, where mortality rate with chemotherapy patients is as high as $49.3 \%$, and with patients who underwent a haematopoietic stem cell transplant it reaches $86.7 \%$. It was also shown that invasive aspergillosis is prevalent more often with the allogeneic bone marrow transplant patients $(2.9-16.0 \%)$, rather than with those who underwent the autologous bone marrow transplant (0.3-1.1\%) (Butrym et al., 2011; Fraquet et al., 2004). Uncharacteristic symptoms and diagnostic difficulties represent a key reason for delayed diagnosis of the infections caused by the fungi of Aspergillus species and deferred commencement of adequate treatment. Chamilos et al. in their research showed that as many as $75 \%$ of fungal infection cases confirmed in post mortem analysis were not diagnosed when the patients were still 
alive (Chamilos et al., 2008). Very often symptoms of fungal infections caused by moulds, are misdiagnosed as bacterial infections. A success case of a 47-year old woman suffering from sarcoidosis, who had been treated with steroids, and for two years had a confirmed lung cavity, indicates that a successful treatment of aspergillosis is possible. In that case, major symptoms of the disease were high fever, chronic cough with sputum, weight loss and hemoptysis. After an ineffective course of antibiotic therapy, the patient was diagnosed with candidiasis and semi-invasive aspergillosis. A computer tomography (CT) scan revealed a mycetoma in the lung cavity, culture of the sputum revealed an Aspergillus infection, and a significant improvement after antifungal treatment confirmed the diagnosis of aspergillosis caused by fungi from A. niger (Kosacka et al., 2010).

At present, the most sensitive test able to confirm aspergillosis is a high resolution CT scan in conjunction with the galactomannan test, which detects the antigen peculiar to Aspergillus. Other molecular recognition techniques based on PCR reaction are also used in detecting nosocomial aspergillosis. Genetic material of a fungus in clinical materials can be isolated by certain starters, e.g. from the sequence of alkaline proteinase or on the basis of 26SrRNA (Kriengkauykiat et al., 2011; Garczewska, 2008, Kędzierska et al., 2007)

Most common forms of nosocomial infections with moulds from the Aspergillus species are as follows:

- $\quad$ aspergilloma located in the lungs, usually after tuberculosis

- invasive aspergilloma (usually the pulmonary variation - in immunocompromised patients, leukaemia and post-transplant patients, in children suffering from chronic granulomatous disease)

- paranasal sinus aspergillosis (in immunocompromised patients)

- central nervous system aspergillosis (accompanies its disseminated version or as a result of sinusitis)

- Aspergillus endocarditis and cardiac aspergillosis - (follow an open-heart surgery)

- eye aspergillosis, endophtalmitis (in patients with endocarditis and following an organ transplant, often as the result of eye injury or transmission via bloodstream)

- aspergillosis of the bone marrow (bone marrow aspergillosis) - in children with granulomatous disease

- disseminated aspergillosis - as oesophageal infection, infection of the intestines, or organ infection: liver, spleen or kidneys.

- chronic necrotising pulmonary aspergillosis - in patients with pulmonary diseases

- skin aspergillosis - in patients with catheters or as the result of transmission via bloodstream.

- $\quad$ allergic bronchopulmonary aspergillosis (asthma) - inhaling spores of fungus by persons allergic to its antigens (Garczewska, 2008).

As previously mentioned, fungi from Aspergillus fumigatus species bear most significant clinical relevance for humans. This fungal species may cause acute and chronic inhalatory respiratory tract infections (aspergillosis, aspergilloma) as well as infections of the hematopoietic system, digestive system, genitourinary tract, skeletal muscles, and nervous system. The primary focus of infection in such cases is usually located in the lungs. Another pathogenic species which causes infections of the respiratory system and which also may cause allergic aspergillosis is Aspergillus flavus. This fungus is also 
responsible for cases of chronic invasive sinusitis as well as deep fungal infections (of the kidneys, endocardium, and central nervous system). Aspergillus ochraceus may be the cause behind antromycosis, pulmonary invasion and onychomycosis. Fungi of the Aspergillus niger species may also cause infections of the inner and outer ear (otomycosis) as well as pulmonary aspergillosis. Similarly to other species of the Aspergillus species, it rarely is responsible for surface aspergillosis. Aspergillus versicolor may constitute an etiological factor for otomycosis, osteomylitis, skin lesions or pulmonary diseases. Recently, clinical significance has been attributed to infections caused by Aspergillus terreus. Its spores may cause an allergic reaction or invasive aspergillosis of the respiratory system, as well as infections of the skin, eye or liver. Aspergillosis in patients with compromised immunity has been attributed more frequently to this species. In retrospective research spanning over 10 years, carried out in Austria (Medical University Hospital of Innsbruck), for 67 cases of invasive aspergillosis, nearly half (32) were infections caused by $A$. terreus, while the remaining cases were attributed to other species of Aspergillus (Lass-Flörl et al., 2005).

\section{Environmental factors facilitating development of fungi of the Aspergillus species}

Environmental parameters adding up to microclimate of rooms which affect people`s physical state comprise: air temperature, relative humidity, airflow in the people zone, purity of the air - both with respect to chemical and microbiological cleanliness, intensity of smells, light and noise levels. Indoors, microclimate is made up of the following factors: outdoor climate, heating and ventilation, people in the room, technological processes which take place inside, thermal characteristics of the room (Kaiser, 2011).

Indoor environment is an active ecosystem which evolves as the time progresses, with changes in humidity, temperature, presence of other microorganisms. Humidity in the rooms designated for people should be between 30-70\%. Excessively humid air encourages multiplication of microorganisms (bacteria, mould), decomposition and water condensation, which increases microbiological contamination of the air. Depending on their designation, temperature in hospital rooms is maintained at different levels, usually falling into the 22$25^{\circ} \mathrm{C}$ temperature brackets.

Moulds grow mainly in the environment where air humidity exceeds $45 \%$, temperature is within the range of $5^{\circ} \mathrm{C}-35^{\circ} \mathrm{C}$ (optimum $18^{\circ}-27^{\circ} \mathrm{C}$ ), and water activity $\mathrm{a}_{\mathrm{w}}$ exceeds 0.8 . Such environment is conducive to production of secondary metabolites - mycotoxins. Penicillium and Aspergillus are dominating mould species in the rooms where water activity is around 0.85 (Jarviss, 2003). Coefficient of hygroscopic expansion $a_{w}$ for fungi is lower than for bacteria, for the latter the prerequisite for development is the 0.99 to 0.995 range. Fungi of the A.flavus type belong to the group of fungi which require higher air and soil humidity. It requires a $0.902 \mathrm{a}_{\mathrm{w}}$ level, which constitutes an extremely humid environment (Zyska, 1999).

Development of fungi may be affected by light in many different ways. Depending on the species, light may inhibit spore development or cause its abundant growth. It has been found that with one of the Alternaria species light of wavelength of $0.415 \times \mathrm{xm}-0.49 \mathrm{xm}$ 
completely blocks spore development, while wavelength below $0.39 \mathrm{xm}$ and exceeding $0.5 x m$ stimulates spore growth (Zyska, 2001).

Influence of hydrostatic pressure on fungi growth has not been adequately researched. Fungi show no sensitivity to hyperbaria. Fungal endospores display a unique resilience to high pressure. Osmotic pressure inside hyphae of some species may be as high as $4255 \mathrm{hPa}$ (Kurnatowska, 1998). Mould conidia of A.niger do not show sensitivity to pressure of $1000 \mathrm{MPa}$. Growth of most yeast is halted, however, at pressure levels of as little as $0.8 \mathrm{MPa}$. A considerable drop in the hydrostatic pressure - hypobaria, or even deep vacuum, do not pose a threat to cells of many types of fungi. Deep vacuum had little or no impact on fungal vegetative forms and endospores, e.g. those from the Cheatomium globosum, Aspergillus oryzae, and Aspergillus terreus species (Piotrowska, 2000).

From among external environmental chemical factors, the most important is acidity or alkalinity, which is measured in $\mathrm{pH}$ parameters. Lowest and highest values on the $\mathrm{pH}$ scale, within the boundaries of growth of a fungus, represent the scope characteristic for a given species. This factor ranging between 5 to 6 is appropriate for most fungi. As in the majority of cases fungi favour $\mathrm{pH}$ below 7, most may be labelled acidophilic. Many species of Aspergillus, Penicillium, and Fusarium may grow at $\mathrm{pH}$ close to 2 . At the same time, species like Penicillium variabilis $i$ Fusarium oxysporum thrive in the environment where $\mathrm{pH}$ reaches 11. It should also be added that fungi trigger a shift in $\mathrm{pH}$ levels in the soil they grow in (Haasum \& Nielsen, 1998).

Fungi belong to aerobes or facultative anaerobes. An oxygen increase in the environment lowers the mycelium mass and starts a degenerative process, however, it does not destroy the fungus. An increase in carbon dioxide content also halts the growth of a fungus (Kurnatowska, 1998).

From among moulds, fungi of the Aspergillus species demonstrate highest pathogenicity; however, despite their prevalence in the environment, they produce fewer mycotoxins than the less prevalent mould of Stachybotrys. It is not a rule of the thumb for all fungi of the Aspergillus species, as sterigmatocystin produced by Aspergillus versicolor may produce approximately $1 \%$ of the total biomass of fungi from this species, with water activity at level 1. This fungus is rarely obtained from indoor environment, as the species occurs in colder regions, in mountain and polar climatic zones. Fungi most often isolated from the indoor air belong to A. fumigatus and A. niger species (Fog Nielsen, 2003).

Among all the microorganisms present in the indoor air, moulds are most prevalent, however, it is crucial to remember, that live microorganisms (bacteria and fungi) make up only $10 \%$ of the total microorganism mass. Survivability of bacteria and moulds in the air is contingent upon peculiar to species susceptibility to desiccation and to the impact of ultraviolet rays. Most susceptible to desiccation are the vegetative forms of bacteria, while the most resilient are fungal spores. Fungal spores measure between 1.5 to $20 \mu \mathrm{m}$. One of the largest spores are: Rhizopus 4- $6 \mu \mathrm{m}$, Mucor 4-8 $\mu \mathrm{m}$, Fusarium 2.4-3.5 $\mu \mathrm{m}$, A. niger 2.5-3.5 $\mu \mathrm{m}$, A. flavus 3.5-4.5 $\mu \mathrm{m}$, while the smallest spores belong to the most pathogenic species of the Aspergillus species: (A. terreus $1.5-2.5 \mu \mathrm{m}$, A. fumigatus 2.5 - $3 \mu \mathrm{m}$, or A. versicolor $2-3.5 \mu \mathrm{m}$ ) (Krzyściak at al., 2011). Figures 1-3 present a scanning microscope image, showing 
conidiophores of fungi of the following species: A. candidus, A. niger and A. flavus. Images from author`s own collection.

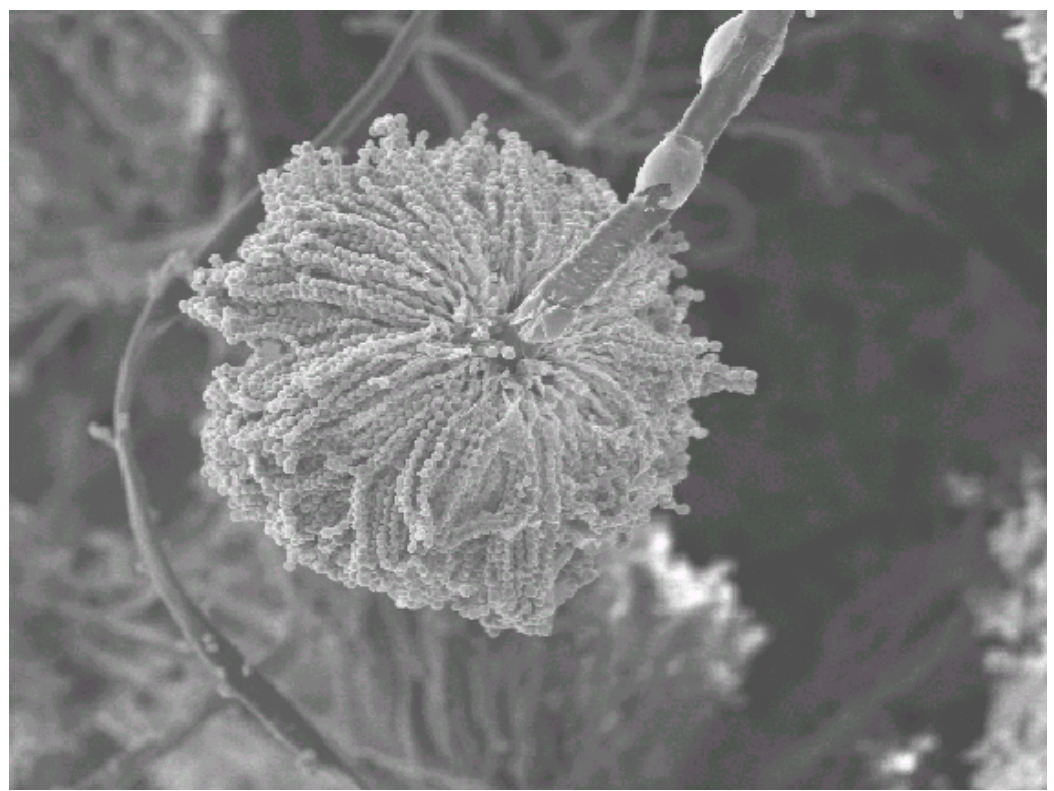

Fig. 1. Aspergillus candidus as seen under the scanning microscope; magnified by 1500x.

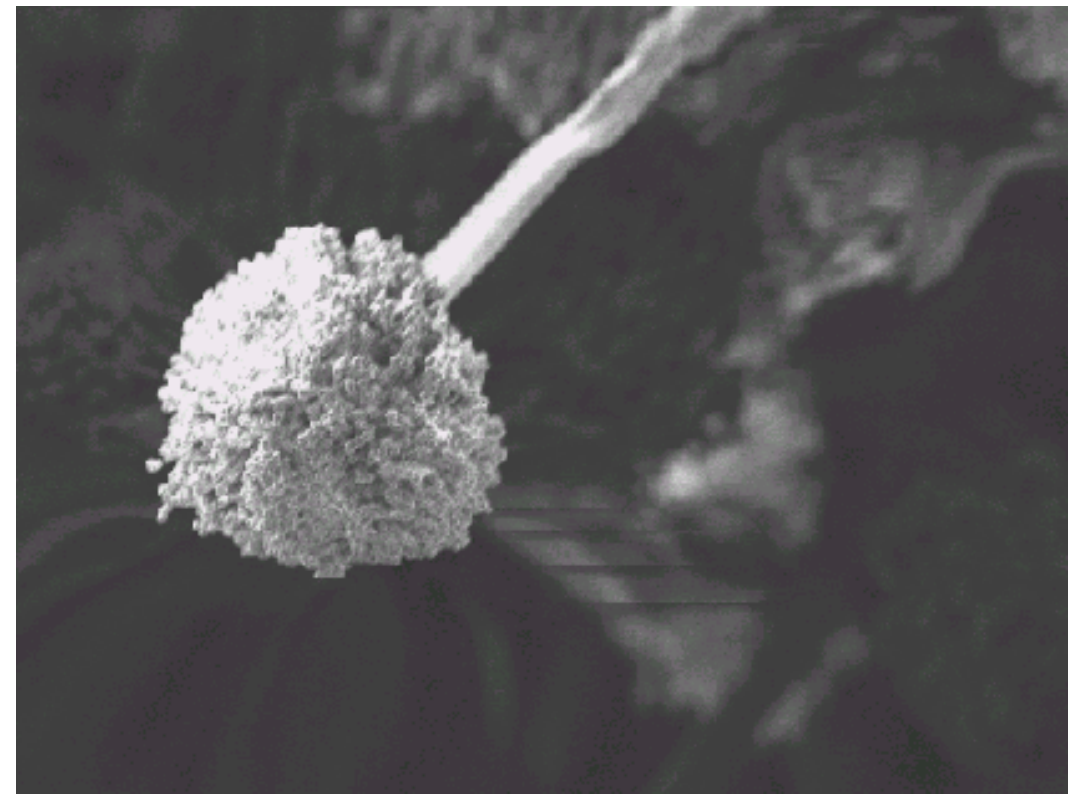

Fig. 2. Aspergillus niger as seen under the scanning microscope; magnified by 1000x. 


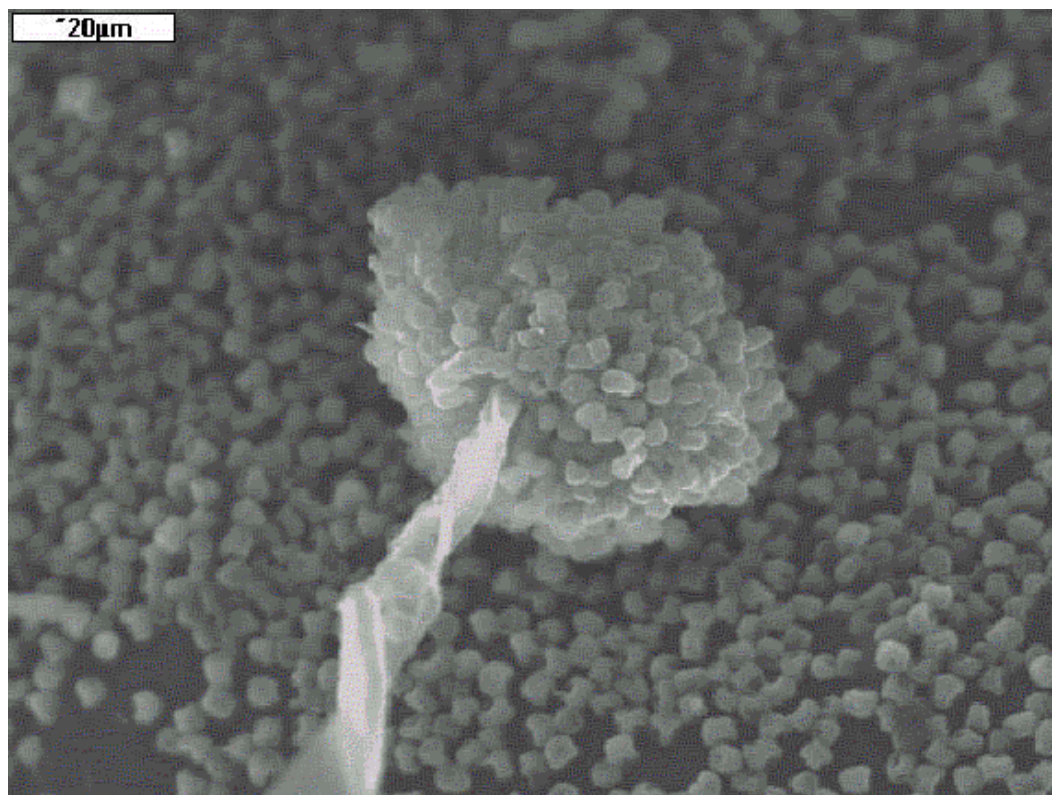

Fig. 3. Aspergillus flavus as seen under the scanning microscope; magnified by 1000x.

In contained rooms, not equipped with specialist ventilation systems and adequate air filtration, fungi and certain bacteria colonize places favourable to their development. Such areas are usually polluted places with increased humidity levels: ventilation shafts, air filters, noise reducing filters, insulation layers, air coolers, humidifier systems. Infected areas of such systems present a secondary source of microbiological contamination of the air. Ventilation and air-conditioning systems are more responsible for polluting the air with fungi than with bacteria. Most serious air infections happen in places where condensation is present. The risk increases if the systems are not properly utilised and if the air contains significant amounts of pollutants (Kaiser, 2011).

Required cleanliness level of air provided for indoors is achieved by filtration by means of air conditioning systems and ventilation equipped with proper filters. For indoor spaces with high hygienic standards it is crucial to implement the use of multi-tier filtration systems. A modern air-conditioning system contains a laminar flow ceiling cabinet. Such system for operating rooms (hospital rooms with high standards of microbiological cleanliness) should provide the necessary amount of fresh air and an adequate frequency of airflow changes per hour. A factor that may limit the occurrence of infections with patients who undergo surgery is creating an environment free from bacteria as well as keeping the surgery time as short as possible (Kremer et al., 2010). Knochen et al. in a study that compared environments of operating theatres, where floors were routinely disinfected after each surgery, with those where theatres were cleaned only when visible dirt appeared, and concluded that none of the procedures influences the number of infections occurring in patients undergoing surgery. Utilizing a laminar flow ceiling cabinet proves to be a sufficient bacteria limiting method (Knochen et al., 2010). 
The problem of providing microbiological cleanliness inside hospital rooms is not exclusively related to observing the principles of air filter exchange in air conditioning systems according to manufacturer`s instructions. According to Kaiser (Kaiser, 2004), periodical ventilation of the air-conditioning system is necessary as well as drying the ventilation pipes and elements of the equipment. He also states that air-conditioning system should not be completely shut off . On the contrary, Dettenkofer et al. suggest that shutting off the ventilation systems in the operating rooms when they are not in use probably does not increase microbiological contamination of the indoor air shortly after the system is switched back on (Dettenkofer et al., 2003).

Proper utilisation of operating rooms also entails isolation of the inner environment from any possibility of contamination access from outside, by maintaining a pressure difference between the inner and outer rooms. Where proper ventilation systems are unavailable, limiting microbiological contamination from staff may result in an approximate twofold reduction in infections. Conclusions of research carried out by Lidwell suggest that with a drop in microbiological contamination concentration of the air below 10 c.f.u/ $\mathrm{m}^{3}$, the drop in risk of infection is minor (Lidwell, 1982). With such low levels of concentration of bacteria in the air, transmission of infectious pathogenic microorganisms this way becomes a less serious cause of infection.

\subsection{Influence of physical and chemical factors on cytotoxicity of fungi}

Fungi are not cytotoxic unless there are circumstances enabling them to produce metabolites. The factors conducive to toxin production include: culture medium, life cycle of the fungi, availability of nutrients, environmental conditions and/or the simultaneous presence of other moulds [Kelman et al., 2004; Pitt et al.,2000). It has been established that in laboratory settings fungal monocultures lose their toxin production potential (Jarvis \& Miller, 2005). Environmental conditions considerably influence the synthesis of fungal virulence factors. When fungal receptors receive variations in such factors as moisture, temperature, water activity and the presence of nitrogen, a signal transduction cascade that controls effector genes expression may be activated, which results in toxin production. The processes of sporulation and mycotoxin production in the Aspergillus fungi are regulated by the protein G transduction signals pathway (Singh \& Del Poeta, 2011). The investigations carried out by Watanabe et al. gave evidence that good environmental conditions, in this case oxygenation, stimulated the $A$. fumigatus fungi to gliotoxin production and were conducive to the increase of their general cytotoxicity (Watanabe et al., 2004).

The presence of the Aspergillus fungi in the human environment does not necessarily cause infection in risk group patients. Those fungi are opportunistic bacteria and are cleared away by means of natural defence mechanisms in healthy individuals, however, they produce severe invasive infections in immunosuppressed patients. So far, the threshold value establishing a requisite for opportunistic infection has not been determined. Therefore, the goal of preventive action should be to eliminate Aspergillus fungi from human environment. Such aim, however, is hard to attain as, obviously, among all bacteria in the air, moulds are most numerous. Methods of absolute elimination of mould spores from the environment have been known, though. Nevertheless, from a practical point of view it is not feasible. Bearing in mind immunosuppressed patients, the Airinspace Technologies system was created. It is based on creating a protective chamber around a patient, where air exchange 
takes place 60 times per hour, with the use of plasma as a bacteria killing agent, it is still very difficult to provide a patient with ultra-sterile air (Poirot et al., 2007).

Our own study on mycological cleanness of hospital rooms indoor air revealed that the Aspergillus species amounted to $20-38 \%$ of all of the moulds isolated, and the most frequently identified species was A. fumigatus [Gniadek et al., 2010; Gniadek et al., 2009). Domination of this species in the indoor air may be tantamount to a high risk of infection. The risk may be confirmed by the findings of Aspergillus cytotoxicity evaluation in such sites as adult intensive therapy ward, intensive neonatal care unit and chemotherapy and radiotherapy wards. The analysis was performed using an MTT test (3-(4.5-dimethylthiazol2-yl) 2.5 diphenyltetrazolium bromide) in which general cytotoxicity was tested on swine kidney cells (SK), sensitive to most mycotoxins. The test is based on the reduction of yellow MTT tetrazolium salt to violet formazan, insoluble in water. The reduction occurs in the presence of intact SK, not damaged by mycotoxins. The intensity of reaction is proportional to the amount of metabolically active SK. When the SK are infected with moulds producing mycotoxins, their mitochondria fail to reduce tetrazolium salt into formazan. Therefore, when the SK are damaged by mycotoxins, the reaction is less intensive or does not occur, which can be measured photometrically as more or less intensive change of colour. Thus, the reduction or the absence of the reaction gives evidence of cytotoxicity of the fungal strain tested (Hanelt et al., 1994).

The analysis comprised the evaluation of a test sample (Petri dish with the moulds on Czapek medium) and a control sample (Petri dish with Czapek medium). The SK were grown in medium containing antibiotics (penicillin and streptomycin, Sigma Aldrich) and calf fetal serum (Sigma Aldrich) in the Hera Cell incubator with carbon dioxide, manufactured by Heraeus $\left(5 \% \mathrm{CO} 2,37^{\circ} \mathrm{C}, 98 \%\right.$ humidity). The number of SK was $2.2 \times 105$. The ranges of testing concentrations were prepared in the ratio 1:2 and amounted from 31.251 to $0.061 \mathrm{~cm}^{2} / 1$. The value was expressed in terms of $\mathrm{cm}^{2} / \mathrm{ml}$, where the area of the Petri dish from which the moulds were extracted together with the medium, was measured in square centimetres.

The quantitative evaluation of cytotoxicity was performed using a microslide spectrophotometer (Elisa Digiscan reader, Asys Hitech $\mathrm{GmbH}$, Austria) and the programme MikroWin 2000 (Mikrotek Laborsysteme $\mathrm{GmbH}$, Germany). The readings were made at the wave-length of $510 \mathrm{~nm}$. All of the absorption values below $50 \%$ of the threshold activity were considered as toxic. So, the borderline toxic concentration was evaluated on the basis of the dilution i.e. the mean inhibitory concentration IC50 was equal to the smallest sample (in $\mathrm{cm} 2 / \mathrm{ml}$ ) which was toxic to the SK. The cytotoxicity was considered as low (+) when the values were within the range of $31.251>15.625>7.813\left[\mathrm{~cm}^{2} / \mathrm{ml}\right]$, intermediate $(++)$ for the values $>3.906>1.953>0.977\left[\mathrm{~cm}^{2} / \mathrm{ml}\right]$, and high $(+++)$ for $>0.488>0.244>0.122>0.061$. The lack of cytotoxicity was reported when the absorption value exceeded $31.251\left[\mathrm{~cm}^{2} / \mathrm{ml}\right]$ (Gareis, 1994).

In own researches for 57 isolated strains - A. fumigatus, A. ochraceus, A. niger, A. flavus, A. versicolor and $A$. ustus, as many as $48(84 \%)$ were cytotoxic. It was also established that the $A$. niger species was considerably less cytotoxic than $A$. ochraceus and A. fumigatus $(\mathrm{p}<0.05)$ (Fig 4). 


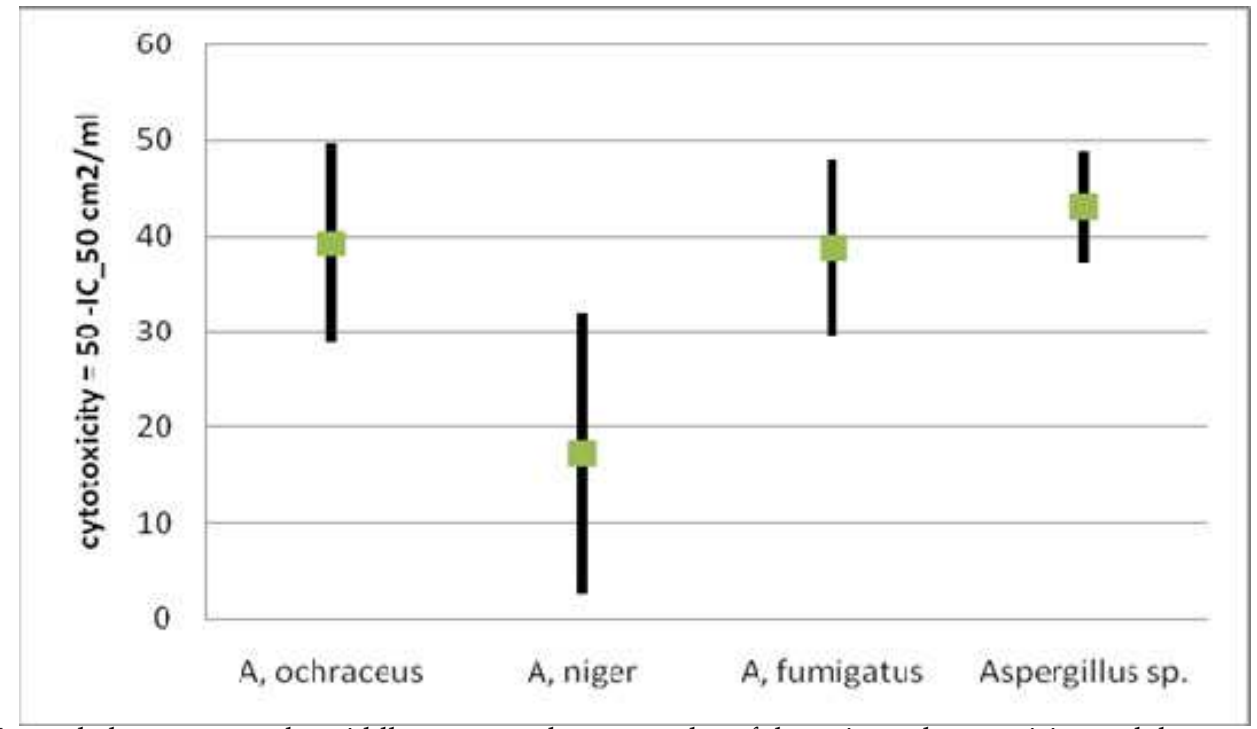

Legend: the squares at the middle represent the mean value of the estimated cytotoxicity, and the vertical lines represent the size of the confidence interval of the estimated cytotoxicity.

Fig. 4. Intervals of confidence $95 \% \mathrm{CI}$ and mean value of Aspergillus cytotoxicity estimated as difference between reference level equal to 50 and measured value of IC $50 \mathrm{~cm}^{2} / \mathrm{ml}$.

Research has shown that among all of the examined strains the strains of A. fumigatus, but not of other species, were either of intermediate or high cytotoxicity (Gniadek et al., 2011). Particularly, eight out of nine strains isolated from indoor air in adult intensive care unit were cytotoxic. High cytotoxicity was found in the following species: A. fumigatus, $A$. ochraceus and A. flavus, while the cytotoxivity of $A$. niger was intermediate or lacked cytotoxicity altogether (Gniadek et al., 2009). A further confirmation of those findings was brought by another study in which the highest fungal virulence towards murine macrophages was found in A. fumigatus, while the lowest in A. niger and A. terreus (Kamei et al., 2002).

The considerable cytotoxicity of fungi isolated from the environment where immunocompromised patients are present encourages intensifying observations concerning the influence of environmental mycobiota on human health. Cases of aspergillosis caused by airborne infections were observed (a patient with aspergilosis infected two other patients in the same intensive therapy unit by airborne route). Recent literature does not provide evidence what level of exposure to toxin producing fungi may be dangerous to the health (Pegues et al., 2002). Nevertheless, there is a common opinion that moulds present indoors may be dangerous and the environmental conditions must be improved. The measurements of environmental occurrence of fungi indoors should include an evaluation of their cytotoxicity when the fungi are known to be toxic. Those measures should be habitual and preventive because evaluation after occurrence of infection will only reflect estimaton of risk at the initial stage of the disease and may not reflect the exposure to harmful substances in the course of the disease. It seems a fair policy that as preventive treatment for patients with 
compromised immunity, in order to contain the exposure, the mycological cleanliness of hospital environment should be monitored, inclusive of marking the cytotoxicity of fungi commonly labelled pathogenic.

\section{Conclusion}

From the epidemiological point of view, the results of exposure to a mix of mycotoxins and other noxious substances present in the air we breathe indoors remain unknown. Therefore, the adverse effect of fungi to human health may be evaluated by means of finding the relationship between the disease (predisposition) and exposure level (detection of pathogenic spores) in relation to symptoms typical for experimental conditions caused by myotoxins.

\section{References}

Asano-Mori, Y. (2010). Fungal infections after hematopoietic stem cell transplantation. International Journal Hematology, Vol. 91, No. 4, pp. 576-587, ISSN 0925-5710

Balajee, S.; Gribskov, J.; Hanley, E.; Nickle, D. \& Marr K. (2005). Aspergillus lentulus sp. nov., a new sibling species of A. fumigatus. Eukaryotic Cell, Vol. 4, No. 3, pp. 625-632, ISSN 1535-9778

Bok, J.; Balajee, S.; Marr, K.; Andes, D.; Nielsen, K.; Frisvad, J. \& Keller, N. (2005). LaeA, a regulator of morphogenetic fungal virulence factors. Eukaryotic Cell, Vol.4, No. 9, pp. 1574-1582, ISSN:1535-9778.

Bräse, S.; Encinas, A.; Keck, J. \& Nising, C. (2009). Chemistry and biology of mycotoxins and related fungal metabolites. Chemical Reviews, Vo. 109, No. 9, pp. 3903-3990, ISSN 0009-2665

Budak, A. (1998). Mikotoksyny, In Zarys mikologii lekarskiej, E. Baran, (Ed.), 533 538, Volumed, ISBN 83- 85564-17-9, Wrocław, Poland

Burr, M. (2001). Health effects of indoor moldes. Reviews on Environmental Health, Vol. 16, No. 2, pp. 97-103, ISSN 0048-7554

Butrym, A.; Zywar, K.; Dzietczenia, J. \& Mazur G. (2011). Invasive fungal infections in patients with hematological malignancies. Mykologia Lekarska, Vol. 18, No. 1, pp. 4753, ISSN 1232-986X

Chamilos, G.; Luna, M.; Lewis, R.; Bodey, G.; Chemaly, R.; Tarrand, J.; Safdar, A.; Raad, I. \& Kontoyiannis, D. (2006). Invasive fungal minfections in patients with hematologic malignancies in a tertiary care center: an autopsy study over a 15 year period (19892003). Hematologica, Vol. 91, No. 7, pp. 986-989, ISSN 0390-6078

Dettenkofer, M.; Scherrer, M.; Hoch, V.; Glaser, H.; Schwarzer, G.; Zentner, J. \& Daschner, E. (2003). Shutting down operating theater ventilation when the theater is not in use: infection control and environmental aspects. Infection Control Hospital Epidemiology, Vol. 24, No. 8, pp.596-600, ISSN 0899-823X

Domsch, K.; Gams, W. \&, Anderson, T. (2007). Compedium of soli fungi ed.2., IHW-Verlag, ISBN 978-3-930167-69-2, Eching, Germany

Fischer, G. \& Dott, W. (2003). Relevance of airborne fungi and their secondary metabolites for environmental, occupational and indoor hygiene. Archives of Microbiology, Vol. 179, No. 2, pp. 75-82, ISSN 0302-8933 
Fischer, G.; Müller, T.; Schwalbe, R.;Ostrowski,R. \& Dott, W. (2000). Species-specific profiles of mycotoxins produced in cultures and associated with conidia of airborne fungi derived from biowaste. International Journal of Hygiene and Environmental Health, Vol. 203, No. 2, pp. 105 - 116, ISSN 1438-4639

Fog Nielsen, K. (2003). Mycotoxin production by indoor molds. Fungal Genetics and Biology, Vol. 39, No. 2, pp. 103-117, ISSN 1087-1845

Fraquet, T.; Gimenez, A. \& Hidalgo, A. (2004). Imaging of opportunistic fungal infections in immunocompromised patient. European Journal of Radiology, Vol. 51, No. 2, pp. 130138, ISSN 0720-048X

Garczewska, B. (2008). Szpitalne zakażenia grzybicze, In: Zakażenia szpitalne, D. Dzierżanowska, (Ed.), 409-425, a- medica press, ISBN 978-83-7522-022-3, BielskoBiała, Poland

Gareis, M. (1994). Cytotoxicity testing of samples originating from problem buildings, In: Fungi and Bacteria in Indoor Air Environments: Health Effects, Detection and Remediation, E. Johanning, (Ed.), 139 - 144, Eastern New York Occupational Health Program, Saratoga Springs, ISBN 0964730707, New York, USA,

Gniadek, A.; Macura, A.B.; Twarużek, M. \& Grajewski, J. (2010). Cytotoxicity of Aspergillus strains isolated from the neonatal intensive care unit environment. Advances in Medical Sciences, Vol. 55, No. 2, pp. 242-249, ISSN 1896-1126

Gniadek, A.; Macura, A.B. \& Twarużek, M. (2009). Characteristics fungi present in the intensive care unit environment. Part 2. Cytotoxicity of the isolated Aspergillus fungi. Mikologia Lekarska, Vol.16, No.1, pp. 15-18, ISSN 1232-986X

Gniadek, A.; Macura, A,B. \& Górkiewicz, M. (2011). Cytotoxicity of Aspergillus fungi isolated from hospital environment. Polish Journal of Microbiology, Vol.60, No.1, pp. 59-63, ISSN 1733-1331

Haasum, I. \& Nielsen, P. (1998). Ecophysiological characterization o common food -borne fungi in relation to $\mathrm{pH}$ and water activity under various atmospheric compositions. Journal of Applied Microbiology, Vol.84, No.3, pp. 451 - 460, ISSN 1364-5072

Hanelt, M.; Gareis, M. \& Kollarczik, B.(1994). Cytotoxicity of mycotoxins evaluated by the MTT-cell culture assay. Mycopathologia, Vol. 128, No. 3, pp. 167 - 174, ISSN 0301486X

Jarvis, B. (2003). Analysis for mycotoxins: the chemist's perspective. Archives of Environmental Health, Vo. 58, No. 8, pp. 479-483, ISSN 0003-9896

Jarvis, B. \& Miller, J. (2005). Mycotoxins as harmful indoor air contaminants. Applied Microbiology and Biotechnology, Vol.66, No.4, pp. 367-372, ISSN 0175-7598

Kaiser, K. (2004). Wpływ zanieczyszczenia instalacji wentylacyjnych i klimatyzacyjnych podczas ich używania na jakość powietrza w obiektach szpitalnych. Technika Chłodnicza i Klimatyzacyja Vol. 98, pp.116-124, ISSN 1231-188X

Kaiser, K. (2011). Jakość powietrza wewnętrznego w szpitalach, In: Profilaktyka zakażeń szpitalnych - bezpieczeństwo środowiska szpitalnego, A. Pawińska, (Ed.), 57-87, amedica press, ISBN 978-83-7522-068-1, Bielsko-Biała, Poland

Kamei, K.; Watanabe, A.; Nishimura, K. \& Miyaji, M. (2002). Cytotoxicity of Aspergillus fumigatus culture filtrate against macrophages. Nihon Ishinkin Gakkai Zasshi, Vol.43, No.1, pp. 37-41, ISSN 0916-4804 
Kelman, B.; Robbins, C.; Swenson, L. \& Hardin, B. (2004). Risk from inhaled mycotoxins in indoor office and residential environments. International Journal of Toxicology, Vol.23, No.1, pp. 3-10, ISSN 1091-5818

Kędzierska, A.; Kochan, P.; Pietrzyk, A. \& Kędzierska, J. (2007). Current status of fungal cell wall components in the immunodiagnostics of invasive fungal infections in humans: galactomannan, mannan and (1-->3)-beta-D-glucan antigens. European Journal of Clinical Microbiology \& Infectious Diseases, Vol. 26, No. 11, pp. 755-766, ISSN 0934-9723

Klich, M. (2009). Health effects of Aspergillus in food and air. Toxicology and Industrial Health, Vol.25, No. 9-10, pp. 657-667, ISSN 0748-2337

Knochen, H.; Hübner, N.; Below, H.; Assadian, O.; Külpmann, R.; Kohlmann, T.; Hildebrand, K.; Clemens, S.; Bartels, C. \& Kramer, A. (2010). Influence of floor disinfection on microbial and particulate burden measured under low turbulance air flow in ophthalmological operation theatres. Klinische Monatsblätter für Augenheilkunde, Vol. 227, No.11, pp.871-878, ISSN 0023-2165

Kosacka, M.; Nawrot, U.; Porębska, I.; Gostkowska A.; Dyła, T. \& Jankowska R. (2010). The case of pulmonary semi-invasive aspergillosis and candidiasis of bronchi in patient with sarcoidosis. Mikologia Lekarska, Vol.17, No.4, pp. 244-247, ISSN 1232-986X

Kramer, A.; Külpmann, R.; Wille, F.; Christiansen, B.; Exner, M.; Kohlmann, T.; Heidecke, C.; Lippert, H.; Oldhafer, K.; Schilling, M.; Below, H.; Harnoss, J. \& Assadian, O. (2010). Importance of displacement ventilation for operations and small surgical procedures from the infection preventive point of view. Zentralblatt fur Chirurgie, Vol.135, No. 1, pp.11-17, ISSN 0044-409X

Kriengkauykiat, J.; Ito, J. \& Dadwal, S. (2011). Epidemiology and treatment approaches in management of invasive fungal infections. Clinical Epidemiology, Vol. 3, pp. 175-191, ISSN 1179-1349

Krzyściak, P.; Skóra, M. \& Macura A.B. (2011). Atlas grzybów chorobotwórczych człowieka, MedPharm POLSKA, ISBN 978-83-60466-80-3, Wrocław, Poland

Kupfahl, C.; Michalka, A.; Lass-Flörl, C.; Fischer, G.; Haase, G.; Ruppert, T.; Geginat, G. \& Hof, H. (2008). Gliotoxin production by clinical and environmental Aspergillus fumigatus strains. International Journal of Medical Microbiology, Vol. 298, No. 3-4, pp.319-327, ISSN 1438-4221

Kurnatowska, A. (1998). Biologia i ekologia grzybów chorobotwórczych, In: Zarys mikologii lekarskiej, E. Baran, (Ed.), 21 - 35,Volumed, ISBN 83-85564-17-9, Wrocław, Poland

Kurnatowski, P. \& Miśkiewicz, S. (2009). Invasive aspergillosis among patients undergoing an transplantation. Mikologia Lekarska, Vol. 16, No.1, pp. 50-53, ISSN 1232-986X

Lass-Flörl, C.; Griff, K.; Mayr, A.; Petzer, A.; Gastl, G.; Bonatti, H,; Freund, M.; Kropshofer, G.; Dierich, M. \& Nachbaur, D. (2005). Epidemiology and outcome of infections due to Aspergillus terreus: 10-year single centre experience. British Journal of Haematology, Vol. 131, No. 2, pp. 201-207, ISSN 0007-1048

Lewis, R.; Wiederhold, N.; Chi, J.; Han, X.; Komanduri, K.; Kontoyiannis, D. \& Prince, R. (2005). Detection of gliotoxin in experimental and human aspergillosis. Infection and Immunity, Vol. 73, No. 1, pp. 635-637, ISSN 0019-9567

Lidwell, O.; Lowbury, E.; Whyte, W.; Blowers, R.; Stanley, S. \& Lowe, D. (1982). Effect of ultraclean air in operating rooms on deep sepsis in the joint after total hip or knee 
replacement: a randomised study. British Medical Journal (Clinical Research ed), Vol. 285, No. 3, pp.10-14, ISSN 0267-0623

Macura, A.B. (1998). Czynniki sprzyjające zakażeniom grzybiczym. In Zarys mikologii lekarskiej, E. Baran, (Ed.), 289 - 295,Volumed, ISBN 83-85564-17-9, Wrocław, Poland

Mortensen, K.; Johansen, H.; Fuursted, K.; Knudsen, J.; Gahrn-Hansen, B.; Jensen, R.;. Howard, S. \& Arendrup, M. (2011). A prospective survey of Aspergillus spp. in respiratory tract samples: prevalence, clinical impact and antifungal susceptibility. European Journal of Clinical Microbiology $\mathcal{E}$ Infectious Diseases, Epub ahead of print, DOI 10.1007/s10096-011-1229-7, ISSN 1435-4373

Pagano, L.; Caira, M.; Nosari, A.; Van Lint, M.; Candoni, A.; Offidani, M.; Aloisi, T.; Irrera, G.;Bonini, A.; Picardi, M.; Caramatti, C.; Invernizzi, R.; Mattei, D.; Melillo, L.; de Waure, C.; Reddiconto, G.; Fianchi, L.; Valentini, C.; Girmenia, C.; Leone, G. \& Aversa, F. (2007). Fungal infections in recipients of hematopoietic stem cell transplants: results of the SEIFEM B-2004 study - Sorveglianza Epidemiologica Infezioni Fungine Nelle Emopatie Maligne. Clinical Infectious Diseases, Vol. 45, No.9, pp. 1161-1170, ISSN 1058-4838

Pegues, D.; Lasker, B.; McNeil, M.; Hamm, P.; Lundal, J. \& Kubak, B. (2002). Cluster of cases on invasive aspergillosis in a transplant intensive care unit: evidence of person - to - person airborne tranmission. Clinical Infectious Diseases, Vol. 34, No. 3, pp. 412416, . ISSN 1058-4838

Piotrowska, M. (2000). Grzyby strzępkowe, In: Mikrobiologia techniczna, Z. Libudzisz \&., K. Kowal, (Ed.), 63-85, Politechnika Łódzka, ISBN 83-87198-5-1, Łódź, Polska

Pitt, J.; Basilico, J.; Abarca, M. \& López L. (2000). Mycotoxins and toxigenic fungi. Medical Mycology, Vol. 38 (Suppl. 1), pp. 41-46, ISSN 1369-3786

Raper, K. \& Fennell D. (1965). The Genus Aspergillus. The Williams \& Wilkins Company. ISBN 978-1-904455-53-0, Baltimore, USA.

Ribeiro, S.; Santana, A,; Arriagada, G.; Martins, J. \& Takagaki, T. (2005). A novel cause of invasive pulmonary infection in an immunocompetent patient: Aspergillus candidus. The Journal of Infection, Vol.51, No. 4, pp. 195-197, ISSN 0163-4453

Richardson, M. (2005). Changing patterns and trends in systemic fungal infections. The Journal of Antimicrobial Chemotherapy, Vol.56, Suppl. 1, pp. 5-11, ISSN 0305-7453

Poirot, J.; Gangneux, J.; Fischer, A.; Malbernard, M.; Challier, S.; Laudinet, N. \& Bergeron, V. (2007). Evaluation of a new mobile system for protecting immune-suppressed patients against airborne contamination. American Journal of Infection Control, Vol.35, No. 7 pp.460-466, ISSN 0196-6553

Shelton, B.; Kirkland, K.; Flanders, W. \& Morris G. (2002). Profiles of airborne fungi in buildings and outdoor environments in the United States. Applied and Environmental Microbiology, Vol.68, No. 4, pp. 1743-1753, ISSN 0099-2240

Singh, A. \& Del Poeta, M. (2011). Lipid signalling in pathogenic fungi. Cellular Microbiology, Vol.13, No. 2, pp.177-185, ISSN 1462-5814

Skaug, M.; Eduard, W. \& Stormer, F. (2001). Ochratoxin A in airborne dust and fungal conidia. Mycopathologia, Vo. 151, No. 2, pp. 93-98, ISSN 0301-486X

Smith, J.; Solomons, G.; Lewis, C. \& Anderson, J. (1995). Role of mycotoxins in human and animal nutrition and health. Natural Toxins, Vol. 3, No. 4, pp.187-192, ISSN 10569014 
Türel, O. (2011). Newer antifungal agents. Expert Review of Anti-Infective Therapy, Vol. 9, No. 3, pp.325-338, ISSN 1478-7210

Watanabe, A.; Kamei, K.; Sekine, T.; Higurashi, H.; Ochiai, E.; Hashimoto, Y. \& Nishimura, K. (2004). Cytotoxic substances from Aspergillus fumigatus in oxygenated or poorly oxygenated environment. Mycopathologia, Vol. 158, No. 1, pp. 1-7, ISSN 0301-486X

Zyska, B. (1999). Zagrożenia biologiczne w budynku, Arkady, ISBN 83-213-4117-9, Warszawa, Poland

Zyska, B. (2001). Katastrofy, awarie i zagrożenia mikrobiologiczne w przemyśle i budownictwie, Politechnika Łódzka, ISBN 83-7283-018-5, Łódź, Poland 


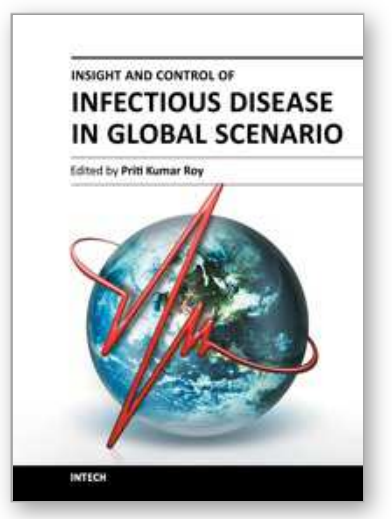

\author{
Insight and Control of Infectious Disease in Global Scenario \\ Edited by Dr. Roy Priti
}

ISBN 978-953-51-0319-6

Hard cover, 442 pages

Publisher InTech

Published online 21, March, 2012

Published in print edition March, 2012

This book is projected as a preliminary manuscript in Infectious Disease. It is undertaken to cover the foremost basic features of the articles. Infectious Disease and analogous phenomenon have been one of the main imperative postwar accomplishments in the world. The book expects to provide its reader, who does not make believe to be a proficient mathematician, an extensive preamble to the field of infectious disease. It may immeasurably assist the Scientists and Research Scholars for continuing their investigate workings on this discipline. Numerous productive and precise illustrated descriptions with a number of analyses have been included. The book offers a smooth and continuing evolution from the principally disease oriented lessons to a logical advance, providing the researchers with a compact groundwork for upcoming studies in this subject.

\title{
How to reference
}

In order to correctly reference this scholarly work, feel free to copy and paste the following:

Agnieszka Gniadek (2012). Cytotoxicity of Aspergillus Fungi as a Potential Infectious Threat, Insight and Control of Infectious Disease in Global Scenario, Dr. Roy Priti (Ed.), ISBN: 978-953-51-0319-6, InTech, Available from: http://www.intechopen.com/books/insight-and-control-of-infectious-disease-in-globalscenario/cytotoxicity-of-the-fungi-aspergillus-as-a-potential-infectious-threat

\section{INTECH}

open science | open minds

\author{
InTech Europe \\ University Campus STeP Ri \\ Slavka Krautzeka 83/A \\ 51000 Rijeka, Croatia \\ Phone: +385 (51) 770447 \\ Fax: +385 (51) 686166 \\ www.intechopen.com
}

\author{
InTech China \\ Unit 405, Office Block, Hotel Equatorial Shanghai \\ No.65, Yan An Road (West), Shanghai, 200040, China \\ 中国上海市延安西路65号上海国际贵都大饭店办公楼 405 单元 \\ Phone: +86-21-62489820 \\ Fax: +86-21-62489821
}


(C) 2012 The Author(s). Licensee IntechOpen. This is an open access article distributed under the terms of the Creative Commons Attribution 3.0 License, which permits unrestricted use, distribution, and reproduction in any medium, provided the original work is properly cited. 